\title{
Gendered Spaces and Prehistoric Households: A Geospatial Analysis of Mumun Period Pithouses from South Korea
}

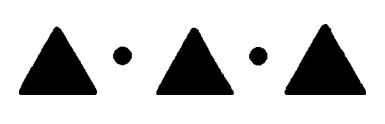

Rachel J. LeE

\begin{abstract}
This article examines pithouse data to ascertain the social dimension of households, namely gender roles and relations, during the Early Mumun and Middle Mumun pottery periods (ca. 1300-500 в.c.) in Chinju [Jinju], South Korea. Pithouses and their interior remains from the Taep'yŏng [RR: Daepyeong] and P'yŏnggŏdong [RR: Pyeonggeodong] sites are analyzed through geospatial and statistical methods. Results indicate that the spatial expression of gender was minimal throughout the Mumun Period despite household space becoming increasingly differentiated. The house was the domain of all genders who largely shared their spaces. Furthermore, the evidence suggests that gender roles were relatively flexible and a gender hierarchy was lacking at the household level. KeYwORDs: Korea, Mumun, households, everyday life, gender, space, geospatial analysis.
\end{abstract}

Engendering prehistory is difficult because archaeologists rarely acquire data that can be readily identified as gendered. However, researchers that ignore gender risk operating under gendered assumptions; this has resulted in the development of uncritical models and androcentric interpretations of prehistory (Brumfiel and Robin 2008:2; Conkey and Spector 1984). Archaeologists must be particularly careful about interpreting data in the Korean context, since the spread of Neo-Confucianism from China is known to have created a gender hierarchy that privileged males. These unequal relationships were codified into law during the Chosŏn Dynasty (1650-1910), which resulted in women becoming successively subordinated to their fathers, husbands, and sons throughout their lives (Deuchler 1992:265; Park and Cho 1995:124-125). Although industrialization and urbanization have since weakened the ideological primacy of Confucianism in South Korea, patriarchy is still relatively pervasive throughout Korean society (Han and Chun 2014:245; Kang 2014). Archaeological research on gender can challenge biases rooted in recent history and make explicit what is and is not inferable from the material record, especially in those regions where ethnographic analogies related to gender must be employed with caution.

In the household context, research on gender also provides an effective method by which the household itself can be studied. Archaeologists often focus on household 


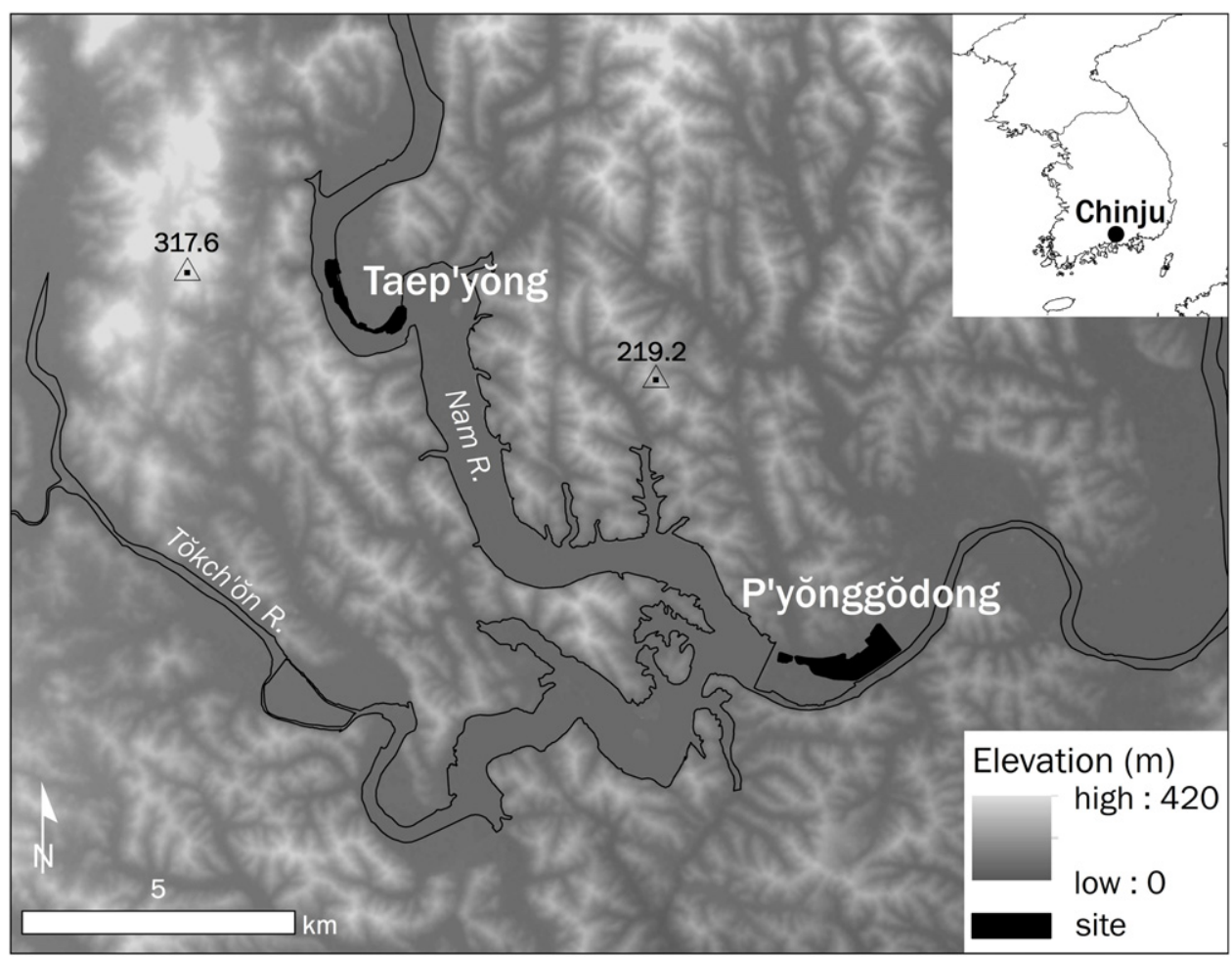

Fig. 1. Digital elevation model of Chinju area (see inset map of Korea), showing approximate locations of Taep'yŏng and P'yŏnggŏdong. Elevation of two mountain summits indicated with triangles (map created using $30 \mathrm{~m}$ elevation SRTM data).

activities due to the nature of the data, which frequently consist of the remains of economic tasks such as food preparation and craft production. The social or relational dimension of the household is less explored and can even be perceived as inaccessible since archaeologists do not directly excavate households, as Wilk and Rathje (1982:620) explained in their defining paper on household archaeology. However, just as activities can be inferred, so can the household as a social unit be inferred through its remains; gender is one way through which the household as a social construct can be accessed by archaeologists (Conkey and Spector 1984:25; Lawrence 1999:122).

This article examines gender in the household context for the Early Mumun (ca. 1300-800 B.C.) and Middle Mumun (ca. 800-500 B.c.) pottery periods in South Korea. The space of the household is chosen as the unit of analysis with the goal of gaining a clearer understanding of the household itself rather than treating this social unit as "faceless blobs" (Tringham 1991:94). I argue that a focus on gender can enrich our understanding of the economic activities that compose most household studies by inserting the people who engaged in those very activities into our analyses (Roth 2010a:3). This is accomplished through the geospatial and statistical analyses of data from Chinju [RR: Jinju], an ideal region for household research as hundreds of pithouses have been excavated in this river valley over the last three decades. Specifically, household data from the P'yŏnggŏdong [RR: Pyeonggeo-dong] and 
ASIAN PERSPECTIVES • $2019 \cdot 58(\mathrm{I})$

Taep'yŏng [RR: Daepyeong] sites suggest that gender roles were relatively flexible and a gender hierarchy was lacking during Early and Middle Mumun periods (Fig. 1).

\section{GENDER, HOUSEHOLDS, AND SPACE}

One of the starting points of gender or gender-aware archaeology has been increasing the visibility of women (Lawrence 1999:121; Nelson 2004:10). As such, the household has been fertile ground as the minimum unit of social reproduction where the presence of women is guaranteed (Tringham 1991:101). Research during the last few decades has underscored the contributions of women in household activities such as craft production, food procurement, food preparation, and labor in general (Hendon 1996:49; Robin and Brumfiel 2008; Roth, 2010a). Beyond their recovery in the archaeological record, the quotidian activities carried out by women are increasingly viewed as intrinsic to the processes structuring society and effecting change at the level of the household and beyond (Claassen 1991; Costin 1993; Jackson 1991; Nelson et al. 2002; Roth 2006; Watson and Kennedy 1998). Indeed, in societies in which men are frequently absent from their home while hunting, herding, or trading, women would have likely held critical positions not only in the maintenance of the household, but also in other parts of the community to which they belonged (Pyburn 2008:120).

Recently, research in gender archaeology has brought the complexities of gender roles, gender attributions, and gender hierarchies into full relief. The universality of structuralist dichotomies that associate women with the home and men with public spheres has been proven false by many studies (Brumfiel and Robin, 2008:2; Gero 1991; Shoocongdej 2002:188-189; Wadley 1998; Zihlman 1998); such binary models are now considered more appropriate for post-industrial societies than prehistoric ones (Hendon 2006:177; Lawrence 1999:121). Even in cases in which gender roles were well-defined, roles designated as 'female', 'male', or another gender may not always have remained stable through time. For instance, Miller (2008) cited a flexible rather than static division of labor as critical for crossing the "economic transition point" between foraging subsistence and agro-pastoralism in North Africa. Likewise, through the analysis of stone tools in Huaricoto, Peru, Gero (1991) contended that the production and use of these objects shifted from mostly males to females through time (see also Tejeda 2008). Gender roles may therefore be more fluid than the idealized versions often projected in archaeological research or even in the culture itself.

Archaeologists also now acknowledge that the salience of gender as an organizing principle varied across space and time. While gender likely structured both horizontal and vertical relationships, particularly in societies with minimal social differentiation, other aspects of identity (e.g., age, ethnicity, lineage, class) may have taken precedence in some cultures (Brumfiel and Robin 2008:4; Pyburn 2008:116). The expectation that one gender was dominant over others or that gender itself was a major dimension of social organization is being reexamined (De Lucia 2008). Archaeological data, therefore, must be evaluated with caution so as not to place unwarranted significance on gender in ordering and categorizing relationships.

Of course, task differentiation by gender was present to some extent in many early societies (Watson and Kennedy 1998:175). Cross-cultural research suggests that certain household activities seem to have been frequently performed by one gender. For example, activities such as food preparation and spinning of fibers have been documented to be primarily the domain of women (Hegmon et al. 2000:48; Nelson 
2004:102, 109; Pyburn 2008:118; Steadman 2015:195). Gender research in archaeology necessitates gender attributions, at least heuristically; otherwise, gender archaeologists create a genderless past, an abstraction rather than an explication, and are then subject to making gendered assumptions themselves (Costin 1996). Models that infer a gendered division of labor without rigidity, as well as methods that make careful associations between gender and material data, are thus essential in pursuing an archaeology of gender (Lawrence 1999:122; Steadman 2015:195; Wadley 2000:154). However, our models and attributions are meaningful only if they are in concordance with the archaeological record and anchored in their proper social contexts, without conflating general patterns with universalities.

Just as status and other categories of identity are inferred through material correlates, inferences about gender are based on household remains that are associated with gendered activities (Conkey and Gero 1991:14; Lawrence 1999:122). These activities are examined through the distribution of artifacts and patterns in the architectural remains of household space (Lee and Bale 2016:179); numerous studies have examined gender in the household context in this way (Bolger 2003; Gibb and King 1991; Hegmon et al. 2000; Hodder 1984; Kus and Raharijaona 1990; Marcus 1998; Nevett 1994; Roth 2010b; Steadman 2015). Household space both facilitates and is shaped by domestic routine (Bourdieu 1977; Giddens 1984), and the daily, repetitive actions of this routine structure space into gendered, gender-neutral, private, shared, or sacred areas. Thus gender relations (and other social constructs) can vary through space (Massey 1994:178) even inside a single enclosure, with the built environment continuing to impart non-verbal behavioral cues (Lawrence and Low 1990:454; Rapoport 1990).

An integral part of the process by which household space (gendered or otherwise) becomes differentiated is the creation of physical and imagined boundaries (Lee and Bale 2016:180). Gender identities and roles are created through repetitive performance (Butler 1988; Goffman 1959). Gendered spaces remain so because household members invest in maintaining the boundaries that define where one activity ends and another begins through these repeated interactions and activities. The fixity and strength of boundaries vary throughout household space, which result in a range of material consequences. The strongest borders are physical (e.g., walls) and tend to separate contrasting activities, producing sharper transitions in the material remains of these spaces (Ashforth et al. 2000; Kooyman 2006). They are effective in not only enclosing areas but also restricting physical and visual access to those spaces (Fisher 2014; Steadman 2015:59). Other boundaries lack tangible barriers but are nonetheless perceived as real (Hall 1990:106). These imagined boundaries, or "mental fences" (Ashforth et al. 2000:474), separate activities that are prone to be similar relative to activities partitioned by physical boundaries. Due to their greater permeability and flexibility, the regularity of these activities often determines how blurred or distinct such boundaries appear in the archaeological record (Kooyman 2006:425-426). The pattern of segmentation in a household space can thus illustrate how household members experienced and treated their place, including their usage of activity areas that may have been gendered (Conkey and Spector 1984:26; Hegmon et al. 2000).

THE CHINJU AREA

Taep'yŏng and P'yŏnggŏdong are located in the city of Chinju near the southern coast of the Korean peninsula (Fig. 1). The city formed along the Nam River, which has 
been an important source of water in the region since prehistoric times. Numerous Mumun period sites have been recovered in Chinju as part of salvage projects due to accelerated economic development of this river valley. The excavation of Taep'yŏng between 1996 and 1999 was among the first of these projects; it was prompted by the repair and reconstruction of a dam that would eventually result in the site being submerged under water (Bale 2008). Situated inside a pronounced meander of the river, Taep'yŏng was excavated by nine different teams, who eventually exposed a total area of 71,953 $\mathrm{m}^{2}$ (Kungnip Chinju 2002:10) to reveal more than 400 Mumun period pithouses, dry agricultural fields, and other features located atop a natural levee (Bale and Ko 2006). AMS radiocarbon dates indicate both an Early Mumun and a Middle Mumun occupation (Crawford and Lee 2003; 2011). Middle Mumun pithouses composed the majority of the dwellings at Taep'yŏng, suggesting that the settlement was relatively small during the Early Mumun period. Additional Mumun sites were also excavated immediately north and south of the meander. Stratigraphic profiles indicate multiple flooding episodes throughout the Mumun period (ca. 1500-200 B.c.), which may have played a part in the subsequent abandonment of the site (Kungnip Chinju 2002:27-28). Taep'yŏng remains one of the most densely occupied Mumun village settlements in South Korea to date.

The excavation of P'yŏnggŏdong was also a salvage project; it preceded the construction of mostly apartment buildings about $12 \mathrm{~km}$ downriver from Taep'yŏng. Located along a curve of the Nam River, the site was excavated between 2005 and 2012 by four institutes. It covers an even larger area $\left(\right.$ ca. 506,823 $\left.\mathrm{m}^{2}\right)$ than Taep'yŏng. Relict dry and wet agricultural fields were recovered there, as well as 73 Mumun pithouses located on the highest parts of what was once a natural levee. Calibrated AMS radiocarbon dates obtained from Mumun features indicate P'yŏnggŏdong was occupied during the Early and Middle Mumun periods (Culleton 2011a, 2011b; Kim and Yun 2011:68; Kyŏngnam Palchŏn 2011c:386-389, 2012b:348-351; Ryu, No, and Sin 2012:389-390; Ryu, So, and Kim 2012:239-240). While a majority of samples $(n=19)$ date to the Early Mumun period at P'yŏnggŏdong (PGD), one AMS radiocarbon date from Locality 3-1 and two dates from Locality 4-2 have midpoints that range between 1330 and 1405 cal. B.C. (Kim and Yun 2011:68; Ryu, So, and Kim 2012:240), which fall within the Incipient Mumun period (ca. 1500-1300 B.c.). However, one of the Incipient Mumun dates from Locality 4-2 was obtained from a pithouse that also produced an Early Mumun date. Based on these results, this article infers an Early Mumun occupation as the first substantial Mumun settlement at P'yŏnggŏdong.

The discussion that follows is based on the analysis of all complete Mumun period pithouses $(n=58)$ from four localities at P'yŏnggŏdong (Kyŏngnam Munhwajae 2012; Kyŏngnam Palchŏn 2011a, 2011b, 2012a; Tongsŏ 2012) (Table 1). A sample of pithouses $(n=33)$ from six localities at Taep'yŏng (TP) are also included (Kungnip Ch'angwŏn 2001, 2003; Kyŏngnam Kogohak 2002; Kyŏngsang 1999; Kungnip Chinju 2001; Tongŭi 2008) (Table 1). The spatial analysis in this study excludes Early Mumun remains from localities in which artifact location was not indicated in reports, which includes P'yŏnggŏdong Locality 3-2-1 as well as all pithouses in the sample from Taep'yŏng. For the Middle Mumun component, the spatial analysis excludes remains from Okpang 1-1 also due to the lack of artifact location in reports. Additionally, a few ambiguous pithouses that could not be dated at P'yŏnggŏdong and Taep'yŏng are excluded. 
Table i. Pithouse Counts and Floor Area Data for Some Localities Comprising P'YǑNGGŎDONG (PGD) AND TAEP'YǑNG (TP) SITES

\begin{tabular}{|c|c|c|c|c|c|c|c|}
\hline \multirow[t]{2}{*}{ LOCALITY } & \multirow[t]{2}{*}{$\begin{array}{c}\text { TOTAL } \\
\text { DWELLINGS }\end{array}$} & \multicolumn{2}{|c|}{$\begin{array}{l}\text { DWELLINGS PER } \\
\text { SUBPERIOD }^{\text {B }}\end{array}$} & \multicolumn{2}{|c|}{$\begin{array}{l}\text { MEAN FLOOR } \\
\text { AREA }\left(\mathrm{M}^{2}\right)\end{array}$} & \multicolumn{2}{|c|}{$\begin{array}{l}\text { ST. DEV. OF FLOOR } \\
\text { AREA }\left(\mathrm{M}^{2}\right)\end{array}$} \\
\hline & & $\mathrm{EM}^{\mathrm{C}}$ & $\mathrm{MM}^{\mathrm{C}}$ & EM & MM & EM & $\mathrm{MM}$ \\
\hline PGD 3-1 & $24(35)$ & 7 & 17 & 120.31 & 18.31 & 22.49 & 4.70 \\
\hline PGD 3-2-1 & $13(15)$ & 4 & 9 & 69.88 & 23.69 & 63.45 & 7.12 \\
\hline PGD 4-1 & $4(5)$ & 4 & - & 82.52 & - & 17.69 & - \\
\hline PGD 4-2 & $18(19)$ & 14 & 4 & 42.69 & 21.90 & 41.01 & 15.13 \\
\hline TP Okpang 1-1 & $13(15)$ & 1 & 12 & 59.67 & 22.62 & - & 8.32 \\
\hline TP Okpang 1-2 & $12(15)$ & - & 12 & - & 19.43 & - & 11.15 \\
\hline TP Okpang 2 & 1 & 1 & - & 51.55 & - & - & - \\
\hline TP Okpang 4 & 5 & 5 & - & 19.00 & - & 7.77 & - \\
\hline TP Okpang 8 & 1 & 1 & - & 32.11 & - & - & - \\
\hline TP Ŏŭn 2 & $1(2)$ & 1 & - & 33.94 & - & - & - \\
\hline
\end{tabular}

${ }^{a}$ Total Dwellings: Number of complete or almost complete pithouses used for calculating mean and standard deviation (number of total dwellings including partially preserved ones).

${ }^{\mathrm{b}}$ Empty cells $(-)$ represent no data or data not included in this study.

${ }^{\mathrm{c}} \mathrm{EM}=$ Early Mumun; $\mathrm{MM}=$ Middle Mumun .

\section{GENDERED SPACES IN EARLY MUMUN HOUSEHOLDS}

Early Mumun houses were semi-subterranean structures with primarily rectangular floor plans (Fig. 2). Although a few pithouses in the sample are less than $20 \mathrm{~m}^{2}$ in floor area, most structures could have housed more than one family, whether stem, nuclear, or otherwise. The labor investment in maintaining a large dwelling for a small household would probably not have been worthwhile in a region with cold winters and primitive heating capabilities. Many of these pithouses are relatively large, with the largest (from P'yŏnggŏdong) measuring $166.40 \mathrm{~m}^{2}$ in floor area. Floor areas vary significantly, resulting in a total mean of $61.10 \mathrm{~m}^{2}$ and a standard deviation of $46.56 \mathrm{~m}^{2}$ $(n=38)$. The large standard deviation is mostly due to variation in the length of pithouses, which likely reflects fluctuations in the developmental cycle of the household (Goody 1958; Kim P. 2011). In fact, at other contemporaneous sites, archaeologists have documented evidence of household members extending one end of the pithouse to accommodate growth (B. Kim 2015:160).

At P'yŏnggŏdong, the artifact count and floor area variables exhibit weak positive correlation as indicated by the Kendall and Spearman rank correlation coefficients ( $\tau=0.27, p=0.05$ and $\rho=0.38, p=0.05$, respectively) for $n=28$. Removal of outliers (pithouses with less than 6 artifacts) result in a moderate to strong correlation ( $\tau=0.51, p=0.0009$ and $\rho=0.68, p=0.0004)$ between the two variables for $n=22$. These tests show variation in the numbers of tools and pottery among pithouses, possibly reflecting a concomitant variation in household size, especially since some correlation exists between artifact count and floor area. Thus, larger pithouses tend to contain a greater number of household objects, further suggesting that Early Mumun pithouse size is a proxy for household size. The data from Taep'yŏng do not show a statistically significant correlation; however, this is at least partially due to the small 


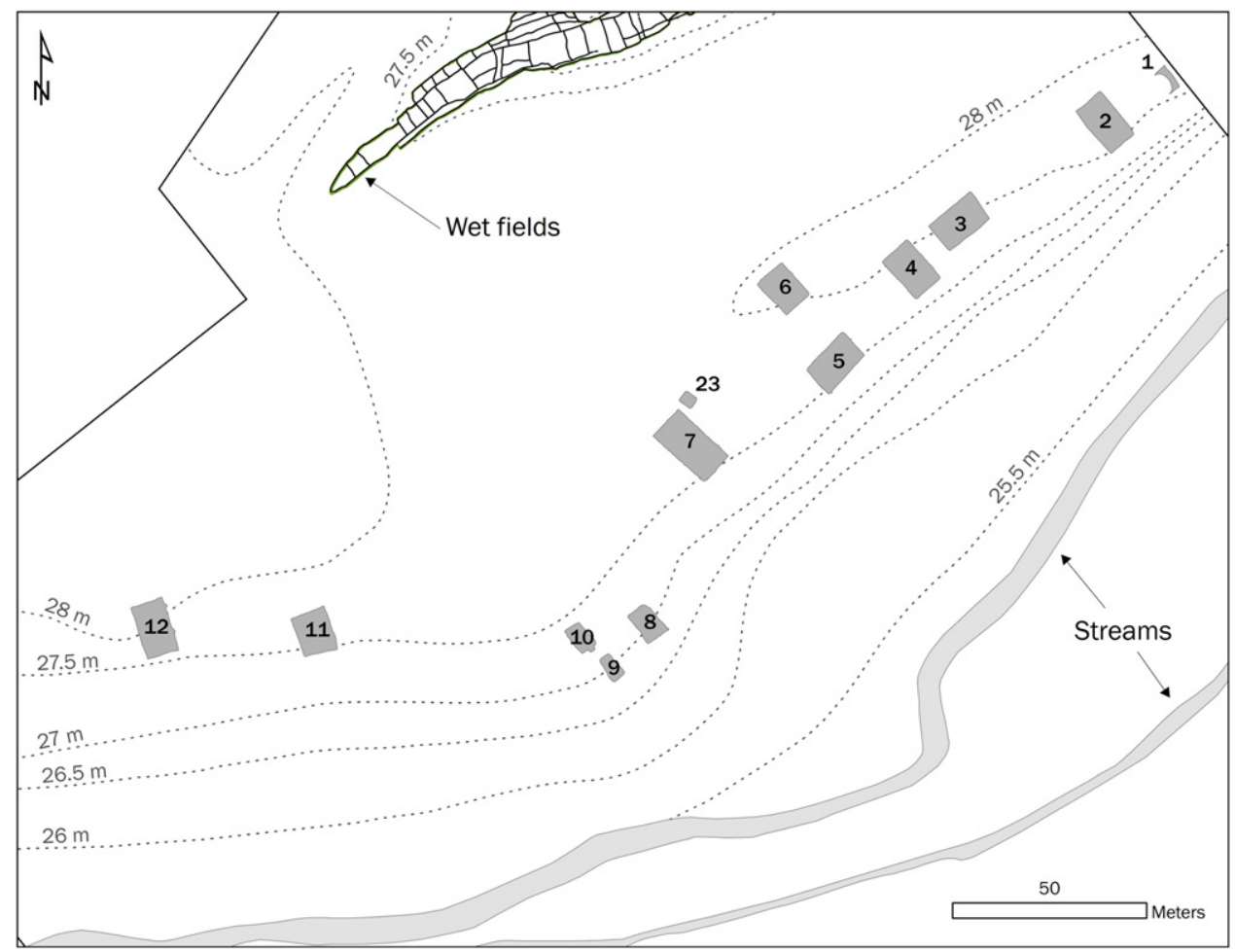

Fig. 2. Map showing location of 13 Early Mumun pithouses (1-12, 23) (dark gray) at P'yŏnggŏdong Locality 3-1. Full extent of Pithouses 1, 8, 9, 10, 11 could not be determined due to post-depositional disturbances (after Kyŏngnam Palchŏn 2011a:47).

sample size $(n=9)$, rendering the tests sensitive to the different preservation conditions of the household remains

Regardless of pithouse size, each structure contained at least one cooking hearth, which was one of the only fixed activity areas in Early Mumun household spaces (Fig. 3). No walled divisions are apparent inside these dwellings, so hearths mark an area characterized as perhaps the most rigid and strongest boundary. These features range from one to four per pithouse at the two settlements, whereas more than ten hearths have been excavated from single pithouses elsewhere in Korea. Possibly a space associated with women's household activities (see below), hearths are centrally located along the long axis of the dwelling or, particularly in larger structures, closer to one or both short walls. When more than one hearth is present, each one was presumably used by a single family. However, hearth count is not a reliable indicator of household size since some of the largest pithouses contain just one hearth. Rather, hearth count and type (i.e., stone or earthen) are mostly tied to the household traditions of the local pithouse group, which has implications for the ways in which spaces, activities, and resources were shared. For instance, almost all pithouses (18 out of 20 ) belonging to the central and eastern pithouse groups at P'yŏnggŏdong contain a single stone hearth. Pithouses located in the western part of P'yŏnggŏdong, however, frequently contain at least two earthen hearths whenever their floor area is greater than $15 \mathrm{~m}^{2}$ (five out of eight). 
(a)

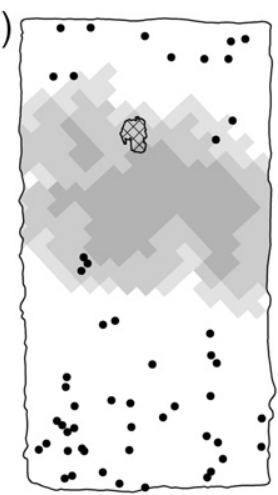

(e)

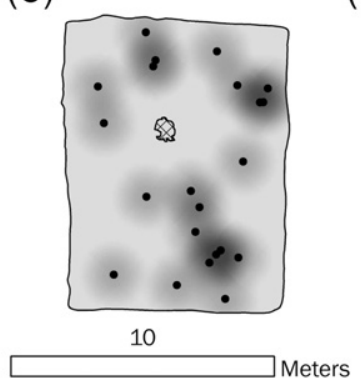

(b)
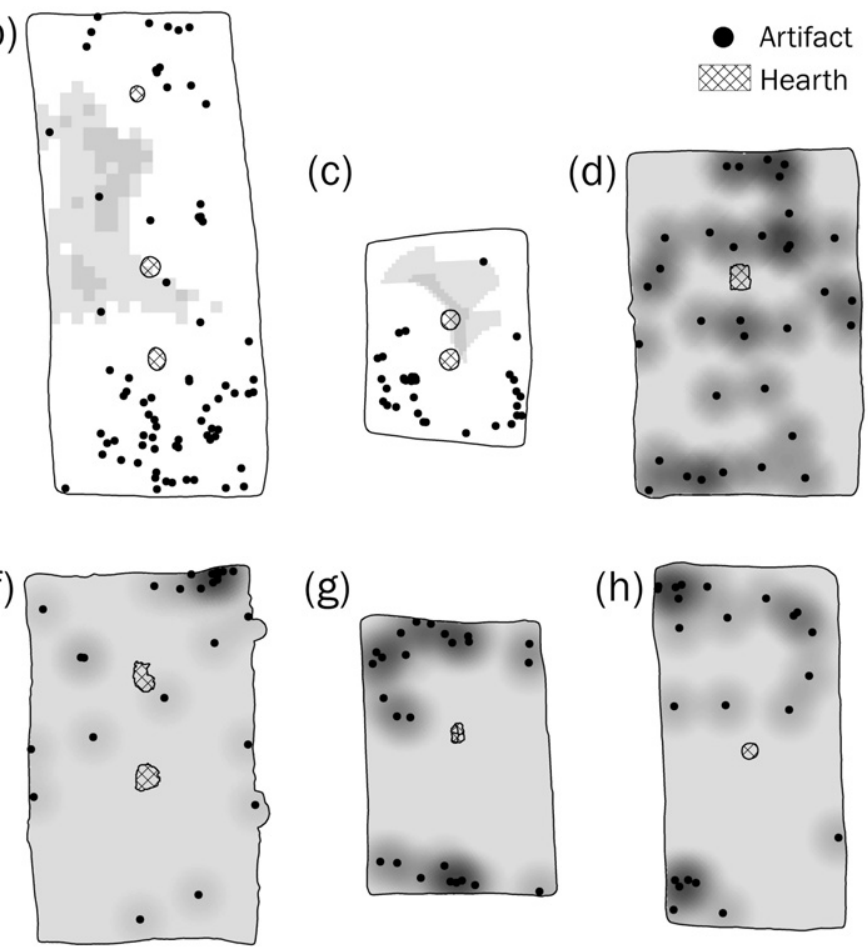

(c)

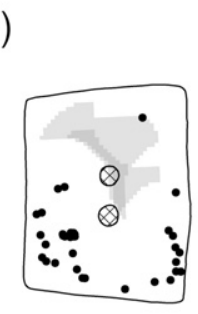

(d)

(g)

Artifact

Hearth

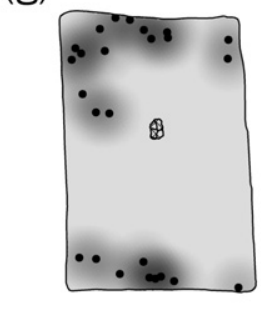

(h)

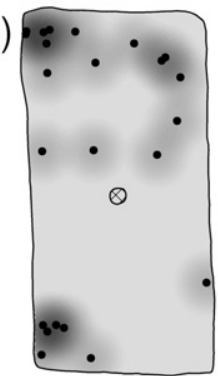

Fig. 3. Spatial clustering of pithouses from P'yŏnggŏdong: (a) Pithouse 7, Locality 3-1; (b) Pithouse 3, Locality 4-2; (c) Pithouse 7, Locality 4-2; (d) Pithouse 4, Locality 3-1; (e) Pithouse 6, Locality 3-1; (f) Pithouse 12, Locality 3-1; (g) Pithouse 3, Locality 4-1; (h) Pithouse 5, Locality 4-2. Pithouses a-c show least spatial clustering (light gray shades) of artifacts based on Getis-Ord $\mathrm{Gi}^{*}$ statistic. Pithouses $\mathrm{d}-\mathrm{h}$ show greatest clustering (dark gray shades) based on Kernel Density Estimation.

Other activity areas can be inferred through the spatial distribution of artifacts excavated from house floors. These artifacts and the paucity of Early Mumun outdoor remains suggest many of the household activities occurred inside the dwelling, although a few pithouses were largely emptied at abandonment. Analyses based on the Average Nearest Neighbor (ANN) statistic, which measures clustering, and the GetisOrd Gi* statistic, which locates clustering (or lack thereof), provide evidence of spatial patterns among some pithouses at P'yŏnggŏdong. First, significant clustering of artifacts, indicated by an ANN ratio of less than 1 , is evident in three of the four pithouses with artifact sample sizes of at least 30 and floor areas greater than $15 \mathrm{~m}^{2}$, including: Pithouse 7, Locality 3-1 (ANN ratio $=0.72, z$-score $=-3.84, p=0.0001$ ); Pithouse 3, Locality 4-2 (ANN ratio $=0.79, z$-score $=-3.40, p=0.0007$ ); and Pithouse 7, Locality 4-2 (ANN ratio $=0.62, z$-score $=-4.39, p=0.00001)$. Second, artifact clustering occurs near one or both short walls, while the central part of the house is relatively empty in the three pithouses. This is evident in Fig. 3a-c, which identifies areas near the hearth as spaces with the lowest values for clustering as suggested by the Getis-Ord Gi* statistic.

Unlike the three pithouses mentioned above, artifacts recovered from Pithouse 4, Locality 3-1 do not exhibit statistically significant clustering. However, visualization 
using Kernel Density Estimation (KDE) shows an empty space, albeit small, around the hearth of this pithouse (Fig. 3d). KDE was also used to visualize the artifact distribution of four other complete dwellings whose sample sizes were too small for the Getis-Ord $\mathrm{Gi}^{*}$ statistic but still contained at least 20 artifacts. As Fig. 3e-h illustrates, artifacts increase in density away from the hearth and often near a wall, which is similar to the pattern seen in Fig. 3a-c. The boundary between artifact-poor and artifact-rich areas (most clearly demonstrated with the Getis-Ord Gi ${ }^{*}$ statistic) may thus represent a partitioning of household space whereby activities such as food preparation and consumption occurred in the vicinity of the hearth while activities associated with clusters of artifacts (e.g., craft production, food and tool storage) occurred on the peripheries of the dwelling or at some distance away from the hearth. The degree of blending between these two areas varies and seems to be related to the length of the house and the proximity of the hearth to the short walls. Similar artifact patterns have been documented elsewhere in Korea (Miyazato 2005; O 2012).

Except for the pattern suggested by the statistical and visualization analyses, no other consistent spatial distribution of artifacts is discernible in the sample. In a few pithouses, pottery as well as stone and ceramic tools are mixed together in the same area. In others, pottery sherds and vessels are located in one part of the dwelling while tools are in another. For example, most of the pottery from Pithouse 7, Locality 4-2 was excavated on the eastern side of the house, while most of the tools were excavated on the western side near the same short wall. Similarly, most of the pottery from Pithouse 3, Locality 4-1 was excavated along the western short wall and most of the tools were found near the corner of the eastern wall on the opposite side. Despite some shared attributes in household space, therefore, the organization of activity areas inside Early Mumun pithouses was relatively flexible at P'yŏnggŏdong.

Of the Early Mumun artifacts, those that may be tentatively attributed to women's activities based on cross-cultural studies are grinding implements and spindle whorls (Nelson 2004:109; Pyburn 2008:118). At Taep'yŏng, only spindle whorls were excavated from four dwellings. At P'yŏnggŏdong, although grinding stones were recovered from nine pithouses, ceramic and stone spindle whorls were represented in more than half $(n=17)$ of the Early Mumun dwellings and was the third most frequently excavated tool. Spindle whorls are also often located near other spindle whorls when found in multiples. This is evident in Pithouse 7, Locality 4-2, which also contains in situ storage vessels (Fig. 4). Most pottery sherds were excavated inside the storage pits, while most tools were excavated near the opposite wall. (As with many other dwellings at P'yŏnggŏdong, there is also evidence of a house fire at Pithouse 7.) However, this spatial association does not suggest gendered spaces, since spindle whorls are almost always excavated in the vicinity of other tools, as discussed above. Furthermore, if whetstones, used in the manufacture of stone tools, can be assigned to the production activities of males, as has traditionally been done, the close proximity of spindle whorls, grinding implements, and whetstones suggests several household activities were performed in a general, non-gendered activity area (Fig. 4).

Evidence of gendered production spaces is likewise absent when considering the proximity between artifacts and features typically recognized as related to female tasks. This is particularly apparent among pithouses with a single hearth located closer to one short wall rather than centrally located. Neither spindle whorls nor grinding stones exclusively occur on the hearth side of the house in Pithouse 7, Locality 3-1; Pithouse 2, Locality 4-1; and Pithouse 2, Locality 4-2, but when they do in other houses, they 
$N$
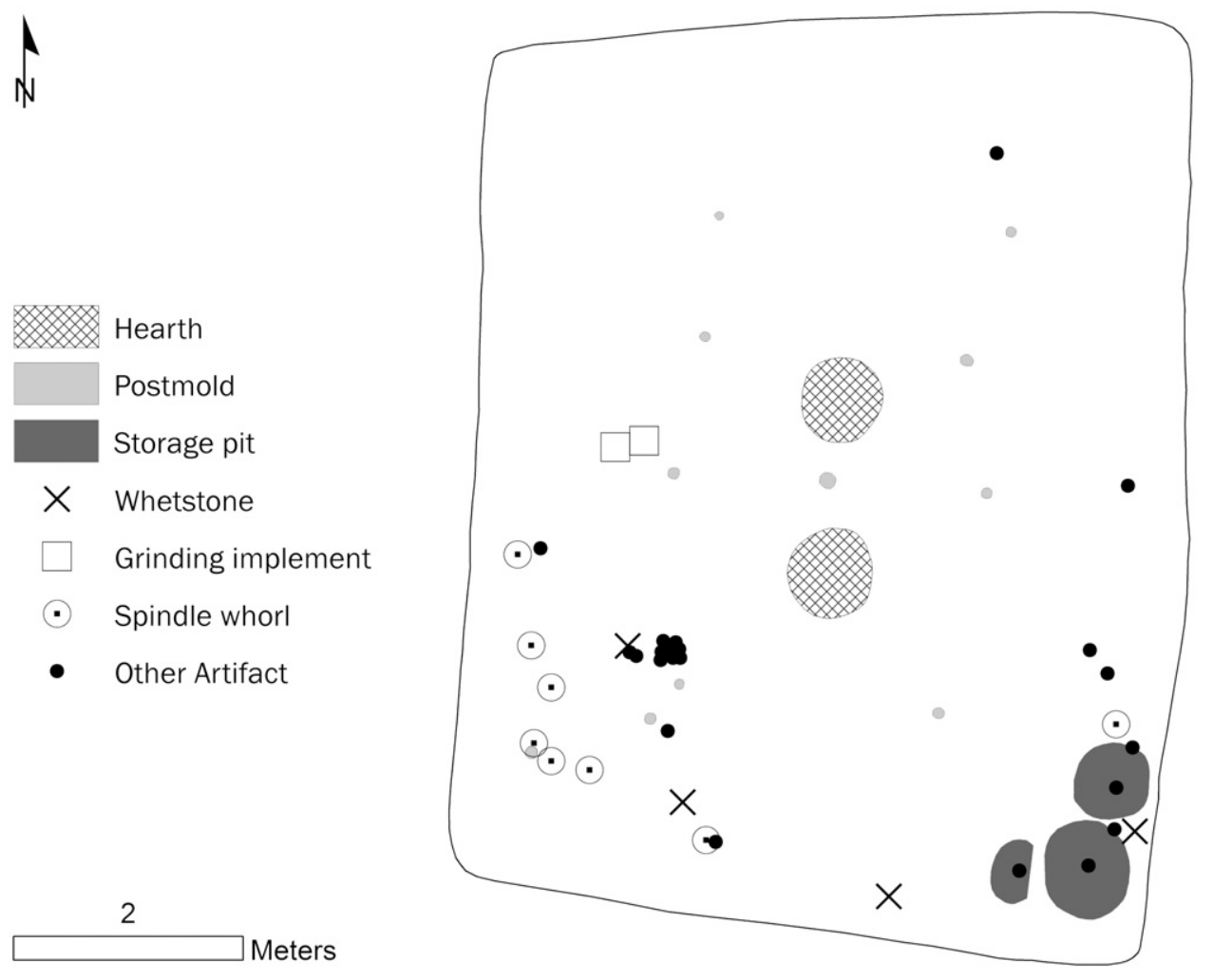

Fig. 4. Artifacts and features of Pithouse 7, Locality 4-2 at P'yŏnggŏdong.

are near other tools such as whetstones. For instance, a grinding implement, spindle whorls, whetstones, and other stone tools were recovered near the walls closest to the hearth in Pithouse 3, Locality 4-1, in a similar pattern to those found in Pithouse 6, Locality 3-1. Where spindle whorls and grinding implements are not present, whetstones are still located around the hearth (i.e., in Pithouses 2, 4, and 5 of Locality 3-1). The cooccurrence of the hearth and storage pits on one side of the house and the prevalence of stone tools on the opposite side have been interpreted as representing female and male activity areas, respectively, at other Early Mumun sites (Kim C. 2011; J. Kim 2011), but evidence for this division is absent at P'yŏnggŏdong. Here, even with the likelihood that some spatial distributions do not represent exact locations of activities due to postdepositional movement or other events, the close proximity of the artifacts rather than a gendered divergence to opposite ends of the dwelling supports a more flexible organization of household space. All genders used the production and storage spaces both near and away from the hearth. Furthermore, segmenting one side of the dwelling as a gendered activity area would not have been conducive in pithouses with multiple hearths or centrally located hearths at P'yŏnggŏdong.

The hearth was therefore possibly the only gendered household space as well as one of the only fixed markers of household activity during the Early Mumun period at Taep'yŏng and P'yŏnggŏdong. The primary internal division of space was between the hearths and the general production and storage areas near one or both short walls. However, despite some of the broad regularities discussed above, household members 
organized their space in a variety of ways. As the open interior spaces suggest (and Fig. 3 illustrates), the multiple single families that composed each household cooperated on tasks and shared many of their resources. Finally and importantly, the household evidence does not suggest production areas were differentiated by gender at P'yŏnggŏdong. The space of the Early Mumun household was thus characterized by minimal gender differentiation as well as minimal boundaries between activity areas, and even these few boundaries were permeable and flexible.

\section{GENDERED SPACES IN MIDDLE MUMUN HOUSEHOLDS}

Pithouses began to decrease in size at the end of the Early Mumun period, continually bringing fewer families under each roof. This trend continued until the Middle Mumun, during which period multifamily households inhabiting rectangular pithouses gave way to single-family households occupying considerably smaller (by floor area) dwellings that were square or circular in plan (Fig. 5). This occurred along with the changes toward greater social, economic, and political complexity that have been covered in detail elsewhere (Bale 2011, 2017; Grier and Kim 2012; B. Kim 2015; Lee and Bale 2016). At Taep'yŏng (Okpang [Okbang] Localities 1-1 and 1-2) and P'yŏnggŏdong, the total mean floor area is $20.68 \mathrm{~m}^{2}\left(\sigma=8.49 \mathrm{~m}^{2}, n=54\right)$,

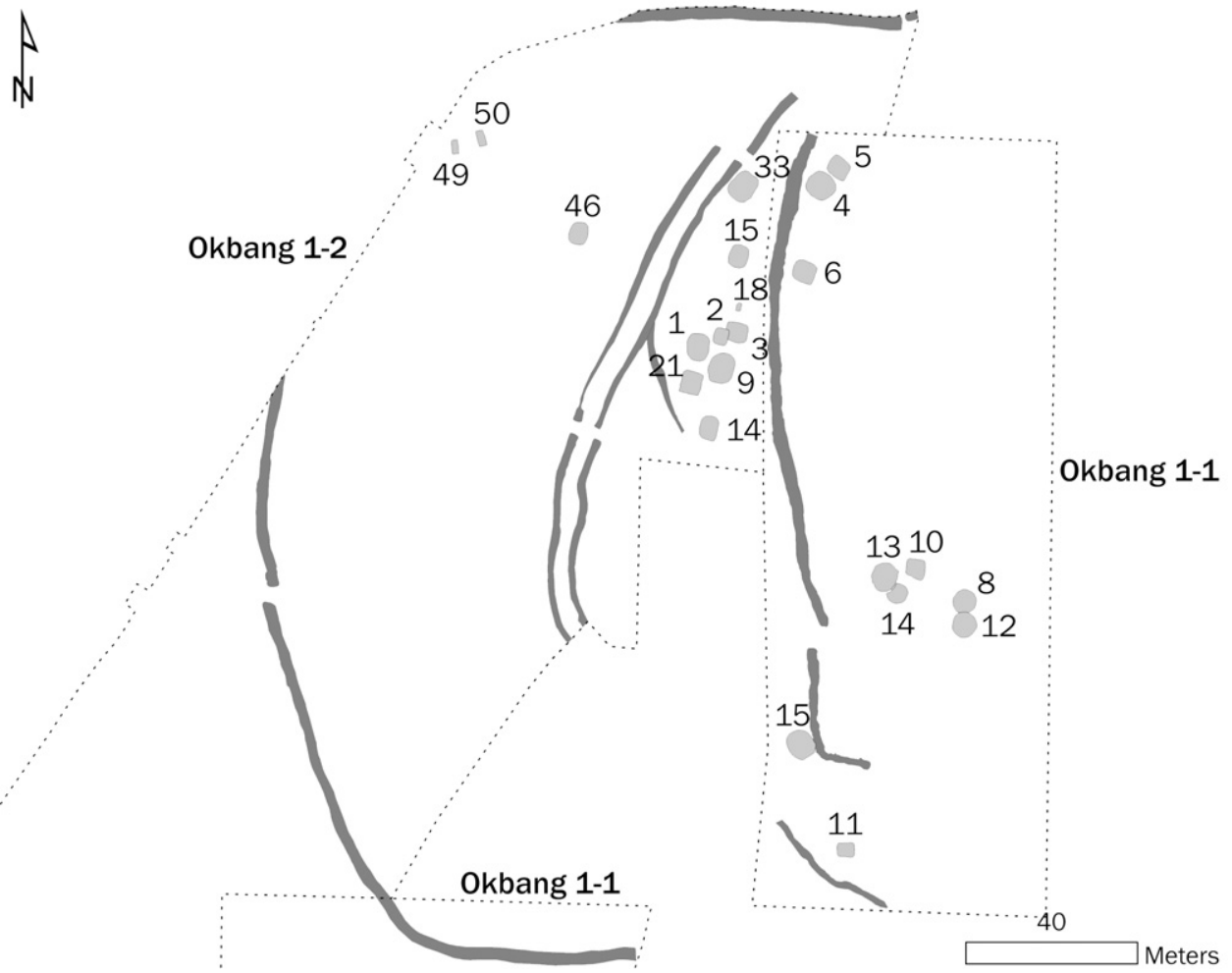

Fig. 5. Middle Mumun pithouses (light gray, labeled by ID no.) located inside ditch enclosures (dark gray), Okpang 1-1 and 1-2 localities at Taep'yŏng. Dashed lines represent locality boundaries. (Middle Mumun pithouses not included in reports for Okpang 1-2 not shown here.) 


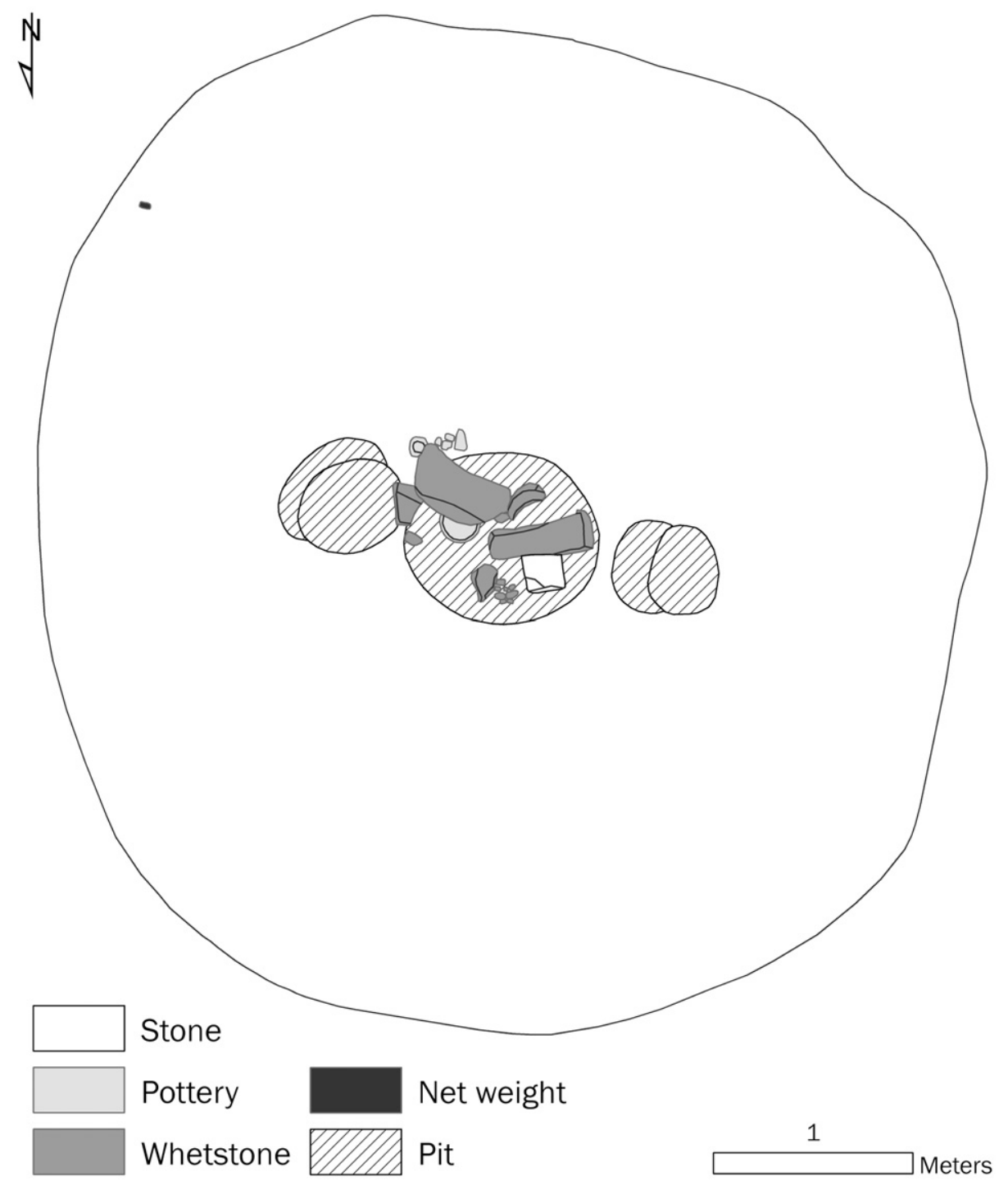

Fig. 6. Pithouse 15, Locality 4-2 (P’yŏnggŏdong) (redrawn from Tongsŏ 2012:131).

representing a 66 percent decrease from the Early Mumun component. The composition of households was therefore dramatically altered. The reduction in space also necessitated change in the organization of Middle Mumun household activities, the most conspicuous being the movement of hearths outdoors. Unlike the previous Early Mumun period, Middle Mumun household space was thus characterized by the house as well as exterior non-architectural elements.

Each Middle Mumun pithouse contains an oval to circular central pit feature, usually flanked by two postmolds (Fig. 6). No other division of space is readily apparent. As Fig. 6 illustrates, central pits are frequently the loci of the densest 
$\stackrel{4}{A}$

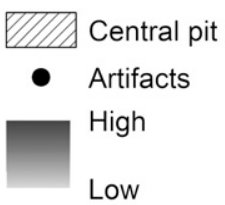

(a)

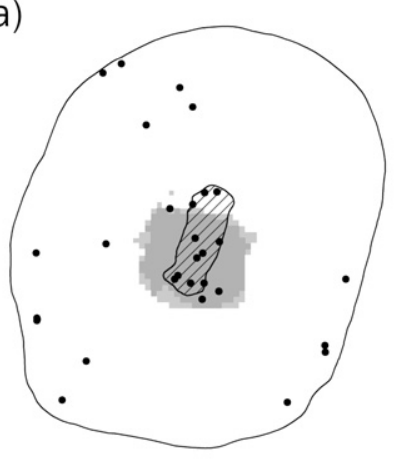

(b)

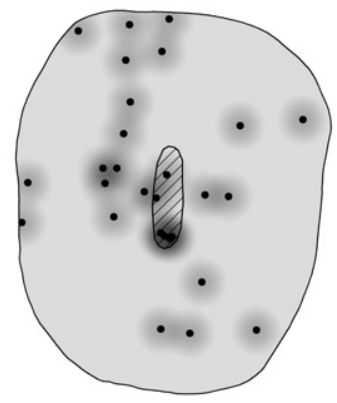

(c)

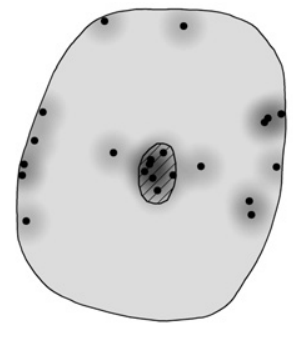

Fig. 7. Three pithouses from Okpang 1-2 (Taep'yŏng): Pithouse 9 (a) shows location of most spatial clustering (gray); Pithouse 1 (b) and Pithouse 46 (c) show clustering (densest areas indicated by darkest shades of gray) based on Kernel Density Estimation.

concentrations of artifacts in the dwelling, with most pithouses containing less than 30 artifacts. Fig. 7a additionally shows significant clustering in the central pit area for Pithouse 9 (TP Okpang 1-2) based on the Getis-Ord Gi ${ }^{*}$ statistic, with clustering confirmed by ANN (ratio $=0.72, z$-score $=-2.90, p=0.004$ ). Although two other pithouses with sample sizes of at least 30 do not exhibit statistically significant clustering, visualization through the KDE suggests greater density of artifacts in the central pit area as well (Fig. $7 \mathrm{~b}, \mathrm{c}$ ).

One of the most frequently excavated artifact types from these pits is a whetstone used in the production of stone tools (Fig. 6). In fact, whetstones make up about 40 percent of the Middle Mumun tool assemblage, compared to just 29 percent for the Early Mumun period at Taep'yŏng and P'yŏnggŏdong. The mean density of these tools also increased diachronically from $0.14(n=35)$ to $0.30(n=45)$ per square meter, a small but statistically significant change as indicated by the Mann-Whitney test $(U=495, p=0.005, r=0.32)$. Furthermore, while central pits from other regions have been documented as storage features, fine stone debris was often found inside or adjacent to these pits at P'yŏnggŏdong and Taep'yŏng (Kyŏngnam Kogohak 2002; Kyŏngnam Munhwajae 2012; Kyŏngnam Palchŏn 2011b; Tongsŏ 2012), suggesting these spaces were used primarily for stone tool production (Tongsŏ 2012:136).

In addition to whetstones, both spindle whorls and grinding implements were excavated from Middle Mumun pithouses. Similar to the Early Mumun pattern, they were located adjacent to other tools. Although the density of grinding tools did not significantly change between the Early and Middle Mumun periods, spindle whorl density decreased diachronically from a mean of $0.04(n=34)$ to $0.02(n=46)$ per square meter, which was shown to be a moderate amount of change based on the Mann-Whitney test $(U=1063, p=0.0009, r=0.37)$. Although further research is 
needed, this may suggest spinning primarily occurred outside of pithouses. Nevertheless, the household evidence indicates the interior space of Middle Mumun dwellings included the activities of all genders, with the only spatial differentiation being the central pit feature. The artifact distribution does not indicate gendered activity areas, which would have been impractical in such small structures.

The only Middle Mumun household space that can be inferred as possibly gendered is the outdoor hearth. Hearths were likely shared by multiple households since they are found in fewer numbers and often several meters away from pithouses. Otherwise, household space was similarly non-gendered as in the previous Early Mumun period, despite an increase in spatial segmentation during the Middle Mumun. Increased spatial segmentation did not result in creating more gendered activity areas, but rather differentiated spaces for single families due to the reduction in pithouse floor area. The household evidence at Taep'yŏng and P'yŏnggŏdong thus suggests that gendered spaces were minimal throughout the Mumun period.

\section{GENDERED SPACES TO GENDER RELATIONS}

The examination of household space is an important way by which gender relations, and by extension the social dimension of the household, can be accessed. Boundaries are encoded with behavioral cues that affect interaction; maintaining such material and social boundaries thus entails personal, community, and institutional costs (Ashforth et al. 2000). Changes in the use and partitioning of space can hence signal concomitant changes in the mechanisms that once maintained these boundaries. The evidence at the P'yŏnggŏdong and Taep'yŏng sites indicates household segmentation increased during the transition to the Middle Mumun period (explained in detail in Lee and Bale 2016). However, gendered spaces remained minimal throughout the Mumun, suggesting gender relations (as expressed through the material remains of the household) were relatively undifferentiated.

The hearth is one activity area that may have been gendered during the Mumun period. The hearth is one activity area that may have been gendered during the Mumun period. If these spaces were indeed gendered (see above), the central location of most hearths inside Early Mumun pithouses not only helped heat these large structures but also effectively positioned women in the center of the dwelling. The multifamily pithouse was the primary space of interaction during this period, the locus of not only economic but also social and political activities. In strong contrast to societies in which women's spaces are located on the margins of the house (Hegmon et al. 2000:49), the central location of hearths would have placed Early Mumun women in a position of greatest visibility and thus enabled them to engage in all household events. In pithouses with a single hearth, this space would have also served as the connecting point for various families residing within the pithouse. When multiple hearths were present, this activity area offered greater autonomy and authority to women in a space and social ethos that otherwise emphasized group-oriented practices. During the subsequent Middle Mumun period, the outdoor location of the hearth suggests that it continued to be a visible space. This is in contrast to other activity areas that became more secluded; for example, stone tool production was now undertaken by single families who resided in separate structures.

Although material remains do demarcate activity areas, these boundaries were largely permeable and flexible. As demonstrated above, several production activities occurred in 
the same general area near walls in Early Mumun pithouses and contributed to the primary division of household space. Beyond this, however, the distribution of artifacts does not distinguish a regular pattern of activity areas based on gender. Artifacts such as grinding implements and spindle whorls do not always co-occur in a given space nor are they only found near hearths or pottery; rather, they are most frequently excavated among other tools such as whetstones. Despite an increase in boundaries (specifically around stone tool production), this pattern continues into the Middle Mumun period. Since a high degree of spatial segregation is often related to well-defined gendered activities, the spatiality of Mumun household activities suggests that any division of labor was not characterized by rigidity but rather integration (Roth 20106; Schriever 2010; Spain 1992; Steadman 2015:214). This is not, however, an argument against a gendered division of labor. Instead, the evidence from Taep'yŏng and P'yŏnggŏdong indicates that the space of Mumun households was conducive to cooperation among household members, regardless of who was using the spindle whorls or whetstones (Wadley 2000:165).

The household data also provides no evidence of a gender hierarchy. As discussed previously, women likely held active and visible roles rather than being spatially and socially marginalized. The open configuration of Early Mumun pithouses, the outdoor location of Middle Mumun hearths, and the relative permeability of household boundaries ensured that no one gender had privileged access to the home or community. This is in contrast to patterns in which the differential status of women is linked to their spatial seclusion or isolation (Steadman 2015:215-217). If a gender hierarchy did exist during the Mumun period, it was not expressed at the household level based on the material evidence.

Finally, this study offers an alternative perspective to the binary model that places women in the home and men in public spaces. During the Early Mumun period, the house was not just the space of women but also of men who performed production activities and socialized in multifamily pithouses. All genders continued to engage in economic tasks inside dwellings during the Middle Mumun, while food preparation moved outdoors. Thus, while gender attributions were heuristically applied to examine Mumun household space, engendering the data such that whetstones are associated with women and spindle whorls are associated with men would still indicate an absence of rigidly gendered activity areas (a pattern that would change only with the spread of Confucianism). Gender attributions are not inherently significant. Rather, they make it possible to interpret the interactions and relationships of household members (Wadley 2000:165), which then helps shift the focus from the material remains of prehistory to the people of prehistory (Conkey and Gero 1991:12-15). This study thus demonstrates the importance of gender archaeology not only for underscoring the complexities and subtleties of gender roles and relations but also for refining our understanding of prehistoric households as a social unit.

\section{REFERENCES CITED}

Ashforth, Blake E., Glen E. Kreiner, and Mel Fugate

2000 All in a day's work: Boundaries and micro role transitions. The Academy of Management Review 25:472-491.

Bale, Martin T.

2008 Archaeological heritage management in South Korea: The Nam River Dam Project, in Early Korea 1: Reconsidering Early Korean History through Archaeology: 213-233, ed. Mark Byington. Cambridge, MA: Korea Institute, Harvard University. 
2011 Storage Practices, Intensive Agriculture, and Social Change in Mumun Pottery Period Korea, 2903-2450 Calibrated Years B.P. Ph.D. diss. University of Toronto, Toronto.

2017 An examination of surplus and storage in prehistoric complex societies using two settlements of the Korean peninsula. World Archaeology 49:90-104.

Bale, Martin T., and Min-Jung Ko

2006 Craft production and social change in Mumun pottery period Korea. Asian Perspectives 45:159-187.

BOLGER, DiANE

2003 Gender in Ancient Cyprus: Narratives of Social Change on a Mediterranean Island. Walnut Creek: Alta Mira Press.

Bourdieu, Pierre

1977 Outline of a Theory of Practice. Cambridge, UK: Cambridge University Press.

Brumfiel, Elizabeth, and Cynthia Robin

2008 Gender, households, and society: An introduction. Archaeological Papers of the American Anthropological Association 18:1-16.

ButLER, JUDiTH

1988 Performative acts and gender constitution: An essay in phenomenology and feminist theory. Theatre Journal 40:519-531.

Claassen, Cheryl P.

1991 Gender, shellfishing, and the Shell Mound Archaic, in Engendering Archaeology: Women and Prehistory: 276-300, ed. Joan M. Gero and Margaret W. Conkey. Oxford: Blackwell.

Conkey, Margaret W., and Joan M. Gero

1991 Tensions, pluralities, and engendering archaeology: An introduction to women and prehistory, in Engendering Archaeology: Women and Prehistory: 3-30, ed. Joan M. Gero and Margaret W. Conkey. Oxford: Blackwell.

Conkey, Margaret W., and Janet D. Spector

1984 Archaeology and the study of gender. Advances in Archaeological Method and Theory 7:1-38.

Costin, Cathy L.

1993 Textiles, women, and political economy in Late Prehispanic Peru. Research in Economic Anthropology 14:3-28.

1996 Exploring the relationship between gender and craft in complex societies: Methodological and theoretical issues of gender attribution, in Gender and Archaeology: 111-140, ed. Rita P. Wright. Philadelphia: University of Pennsylvania Press.

Crawford, Gary W., and Gyoung-Ah Lee

2003 Agricultural origins in the Korean Peninsula. Antiquity 77:87-95.

Culleton, Brendan J.

$2011 a$ Direct AMS ${ }^{14} \mathrm{C}$ dating of plant domesticates from Pyeonggeo-dong, Korea, in Chinju P'yŏnggŏ-dong 3-1 chigu yujŏk VI [Locality 3-1 of the Pyeonggeo-dong Site, Jinju, Vol. VI]: 372-375. Haman: Kyŏngnam Paljŏn Yŏn'guwŏn Yŏksa Munhwa Sentŏ.

$2011 b$ Direct AMS ${ }^{14} \mathrm{C}$ dating of charcoal and short-lived samples from Pyeonggeo-dong, Korea, in Chinju P'yŏnggŏ-dong 3-1 chigu yujŏk VI [Locality 3-1 of the Pyeonggeo-dong Site, Jinju, Vol. VI]: 377-385. Haman: Kyŏngnam Paljŏn Yŏn'guwŏn Yŏksa Munhwa Sentŏ.

De LuCIA, Kristin

2008 Looking beyond gender hierarchy: Rethinking gender at Teotihuacan, Mexico. Archaeological Papers of the American Anthropological Association 18(1):17-36.

Deuchler, Martina

1992 The Confucian Transformation of Korea: A Study of Society and Ideology. Cambridge: Harvard University Press.

FISHER, KeVIN D.

2014 Rethinking the Late Cypriot built environment: Households and communities as places of social transformation, in The Cambridge Prehistory of the Bronze and Iron Age Mediterranean: 399-416, ed. A. Bernard Knapp and Peter van Dommelen. Cambridge: Cambridge University Press. 
Gero, JoAn M.

1991 Genderlithics: Women's roles in stone tool production, in Engendering Archaeology: Women and Prehistory: 163-193, ed. Joan M. Gero and Margaret W. Conkey. Oxford: Blackwell.

Gibb, James G., AND Julia A. King

1991 Gender, activity areas, and homelots in the $17^{\text {th }}$-century Chesapeake region. Historical Archaeology 25:109-131.

GidDENS, ANTHONY

1984 The Constitution of Society. Cambridge, UK: Polity Press.

GoFFMAn, ERving

1959 The Presentation of Self in Everyday Life. Garden City, NY: Anchor Books.

GOODY, JACK, ED.

1958 The Developmental Cycle in Domestic Groups. Cambridge, UK: Cambridge University Press.

Grier, Colin, ANd Jangsuk Kim

2012 Resource control and the development of political economies in small-scale societies: Contrasting prehistoric Southwestern Korea and the Coast Salish region of Northwestern North America. Journal of Anthropological Research 68:1-34.

Hall, Edward T.

1990 The Hidden Dimension. New York: Anchor Books.

Han, Ju Hui Judy, and Jennifer J. Chun

2014 Introduction: Gender and politics in contemporary Korea. The Journal of Korean Studies $19(2): 245-255$.

Hegmon, Michelle, Scott G. Ortman, and Jeannette L. Mobley-Tanaka

2000 Women, men, and the organization of space, in Women and Men in the Prehispanic Southwest: Labor, Power, and Prestige: 43-90, ed. Patricia L. Crown. Sante Fe: School of American Research.

Hendon, Julia A.

1996 Archaeological approaches to the organization of domestic labor: Household practice and domestic relations. Annual Review of Anthropology 25:45-61.

2006 The engendered household, in Handbook of Gender in Archaeology: 171-198, ed. Sarah M. Nelson. Lanham, MA: AltaMira Press.

HODDER, IAN

1984 Burials, houses, women and men in the European Neolithic, in Ideology, Power and Prehistory: 51-68, ed. Daniel Miller and Christopher Tilley. Cambridge, UK: Cambridge University Press.

JACKSON, THOMAS L.

1991 Pounding acorn: Women's production as social and economic focus, in Engendering Archaeology: Women and Prehistory: 301-325, ed. Joan M. Gero and Margaret W. Conkey. Oxford: Blackwell.

KANG, YoOnJUNG

2014 Love and money: Commercial postpartum care and the reinscription of patriarchy in contemporary South Korea. The Journal of Korean Studies 19(2):379-397.

KIM, BumCHEOL 김범철 [see also KIM PŎMCH’ŏL]

2015 Socioeconomic development in the Bronze Age: Archaeological understanding of the transition from the Early to Middle Bronze Age, South Korea. Asian Perspectives 54(1):144-184.

KIM CHONGIL 김종일 [see also KIm, JongIL]

2011 Han'guk Sŏnsasidae Yŏsŏnggwa Yŏsŏngsŏng 韓國先史時代女性과 女性性 [A study of women and female identity in Korean prehistory]. Han'guk gogo hakpo 韓國考古學報 [Journal of the Korean Archaeological Society] 78:5-28.

KIM, JongIL 김종일 [see also KIM CHONGIL]

2011 Women and femininity in Prehistoric Korea. Journal of Korean Art and Archaeology 5:79-89.

Kim, MinkoO, AND Ho-PiL Yun

2011 The availability and use of wood resources at the multi-period settlement site of Pyeonggeodong, Jinju, South Korea. Vegetation History and Archaeobotany 20:67-77.

KIM PŎMCH’ŏL 김범철 [see also KIM, BuMCHEOL]

2011 Ch’ŏngdonggishidae Chŏn'gi Chugŏ Yangsanggwa Kagu Baltalchugi: Hosŏchiyŏk yŏksamdong mit Hŭnam-ri yuhyŏng Ch'wirakŭl Chungshimŭro 靑銅器時代 前期 住居 
樣相과 家口發達週期: 호서지역 驛三洞 吕 欣岩里類型 聚落을 중심으로 [Dwelling patterns and household developmental cycle during the Early Bronze Age: With special reference to Yeoksam-dong and Heunam-ri type settlements of the Hoseo region]. Han'guk sanggosa hakpo 韓國上古史學報 [Journal of the Korean Ancient Historical Society] $72: 31-60$

KOOYMAN, BRIAN

2006 Boundary theory as a means to understanding social space in archaeological sites. Journal of Anthropological Archaeology 25:424-435.

Kungnip Ch'Angwŏn Munhwajae Yŏn'guso 國立昌原文化財研究所 [Changwon National Research Institute of Cultural Heritage]

2001 Chinju Taep'yŏng-ni Ŏŭn 2-chigu sŏnsa yujŏk I 晋州 大坪里 漁隱 2 地區 先史遺蹟 I [The Eoeun 2 Locality of the Prehistoric Daepyeong-ri Site, Jinju I]. Ch'angwŏn: Kungnip Ch'angwŏn Munhwajae Yŏn'guso.

2003 Chinju Taep'yŏng-ni Okpang 8-chigu sŏnsa yujŏk 晋州 大坪里 玉房 8 地區 先史遺蹟 [The Okbang 8 Locality of the Prehistoric Daepyeong-ri Site, Jinju]. Ch'angwŏn: Kungnip Ch'angwŏn Munhwajae Yŏn'guso.

Kungnip Chinju Pangmulgwan 國立晉州博物館 [Jinju National Museum]

2001 Chinju Taep'yŏng-ni Okpang 1-chigu yujŏk (1-ch'a palgul) 진주 대평리 옥방 1 지구 유적 (1 차 발굴) [The Okbang 1 Locality of the Daepyeong-ri Site, Jinju (Excavation Phase 1)]. Chinju: Kungnip Chinju Pangmulgwan.

2002 Ch’ŏngdonggi side ŭi Taep'yŏng, Taep'yŏngin 청동기시대의 大坪, 大坪人 [Daepyeong: Organized Community of the Bronze Age]. Chinju: Kungnip Chinju Pangmulgwan.

Kus, Susan, and Victor Raharijaona

1990 Domestic space and the tenacity of tradition among some Betsileo of Madagascar, in Domestic Architecture and the Use of Space: An Interdisciplinary Cross-Cultural Study: 21-33, ed. Susan Kent. Cambridge, UK: Cambridge University Press.

KYŎNGNAM KOGOHAK YŎN'GUSO 慶南考古學研究所 [GYEONGNAM ARCHAEOLOGICAL ReSEARCH INSTITUTE] 2002 Chinju Taep'yŏng Okpang 1, 9-chigu Mumun sidae chimnak 晋州 大坪玉房 1-9地區 無文時代 集落 [The Mumun Period Settlement of the Okbang Localities 1 and 9 in Daepyeong, Jinju]. Chinju: Kyŏngnam Gogohak Yŏn'guso.

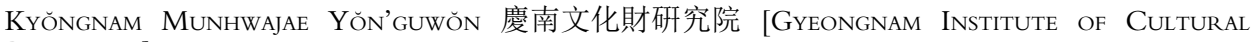
Properties]

2012 Chinju P'yŏnggŏ-dong Yujŏk III: Chinju P'yŏnggŏ 3t'aekchi kaebal să̌p chigu (2-chigu) 진주 평 거동 유적 III: 진주 평거 3택지 개발사업지구 (2지구) [Locality 3-2 of the Pyeonggeo-dong Site, Jinju, Vol. III]. Ch'angwŏn: Kyŏngnam Munhwajae Yŏn'guwŏn.

KYŎNGNAM PALCHŎN YŎN'GUWŎN YŎKSA MUNHWA SENTǑ 慶南發展研究院 歷史文化卅E

[Gyeongnam Development Institute Center for History and Culture]

2011a Chinju P'yŏnggŏ 3-1 chigu yujŏk I 진주 평거 3-1지구 유적 I [Locality 3-1 of the Pyeonggeodong Site, Jinju, Vol. I]. Haman: Kyŏngnam Palchŏn Yŏn'guwŏn Yŏksa Munhwa Sentŏ.

2011 b Chinju P'yŏnggŏ 3-1 chigu yujŏk II 진주 평거 3-1지구 유적 II [Locality 3-1 of the Pyeonggeodong Site, Jinju, Vol. II]. Haman: Kyŏngnam Palchŏn Yŏn'guwŏn Yŏksa Munhwa Sentŏ.

2011c Chinju P’yŏnggŏ 3-1 chigu yujŏk VI 진주 평거 3-1지구 유적 VI [Locality 3-1 of the Pyeonggeo-dong Site, Jinju, Vol. VI]. Haman: Kyŏngnam Palchŏn Yŏn'guwŏn Yŏksa Munhwa Sentǒ.

2012a Chinju P'yŏngğ 4-1 chigu yujǒk I 진주 평거 4-1지구 유적 I [Locality 4-1 of the Pyeonggeodong Site, Jinju, Vol. I]. Haman: Kyŏngnam Palchŏn Yŏn'guwŏn Yŏksa Munhwa Sentŏ.

2012 b Chinju P'yŏnggŏ 4-1 chigu yujŏk II 진주 평거 4-1지구 유적 II [Locality 4-1 of the Pyeonggeodong Site, Jinju, Vol. II]. Haman: Kyŏngnam Palchŏn Yŏn'guwŏn Yŏksa Munhwa Sentŏ.

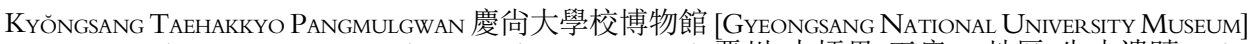
1999 Chinju Taep'yŏngni Okpang 2-chigu sŏnsa yujŏk 晋州 大坪里玉房 2 地區 先史遺蹟 [The Okbang 2 Locality of the Prehistoric Daepyeong-ri Site, Jinju]. Jinju: Kyŏngsang Taehakkyo Pangmulgwan.

Lawrence, Denise L., and Setha M. Low

1990 The built environment and spatial form. Annual Review of Anthropology 19:453-505. 
LAWRENCE, SUSAN

1999 Towards a feminist archaeology of households: Gender and household structure on the Australian goldfields, in The Archaeology of Household Activities: 121-141, ed. Penelope M. Allison. London: Routledge.

Lee, Gyoung-Ah

2011 The transition from foraging to farming in prehistoric Korea. Current Anthropology 52:307-329.

Lee, Rachel J., and Martin T. Bale

2016 Social change and household geography in Mumun period South Korea. Journal of Anthropological Research 72(2):178-199.

Marcus, Joyce

1998 Women's Ritual in Formative Oaxaca: Figurine-Making, Divination, Death and the Ancestors. Memoirs of the Museum of Anthropology, University of Michigan No. 33. Ann Arbor, MI: University of Michigan.

MASSEy, DOREen

1994 Space, Place, and Gender. Minneapolis: University of Minnesota Press.

Miller, Alexandra

2008 Changing responsibilities and collective action: Examining early North African pastoralism. Archaeological Papers of the American Anthropological Association 18:76-86.

Miyazato Osamu 宮里 修

2005 Mumun t'ogi sidea ŭi ch'wirak kusŏng: chungsŏbu chiyŏk ŭi Yŏksam-dong yuhyŏng 無文土 器時代의 취락 구성: 中西部地域의 驛三洞 類型 [Settlement patterns of the Yeoksamdong assemblage in central-western Korea]. Han'guk kogo hakpo 韓國考古學報 56:49-92.

Nelson, Margaret, Donna Glowacki, and Annette Smith

2002 The impact of women on household economies: A Maya case study, in In Pursuit of Gender: Worldwide Archaeological Approaches: 125-154, ed. Sarah M. Nelson and Myriam RosenAyalon. Lanham, MA: AltaMira Press.

Nelson, SARAh M.

2004 Gender in Archaeology: Analyzing Power and Prestige. Walnut Creek, CA: AltaMira Press.

NeVETt, Lisa

1994 Separation or seclusion: Towards an archaeological approach to investigating women in the Greek household in the fifth to third centuries BC, in Architecture and Order: Approaches to Social Space: 98-112, ed. M. Parker Pearson and C. Richards. London: Routledge.

O YONGJE 오용제 [OH YONGJE]

2012 Ch'ŏngdonggi sidae chŏngi chuğji naebu ŭi konggan hwaryong yangsang yŏn'gu 청 동기시 대 전기 주거지 내부의 공간 활용 양상 연구 [A Study on the Use of Space in Korean Early Bronze Age Pit-houses]. M.A. thesis. Seoul National University, Seoul.

Park, Insook Han, and Lee-Jay Cho

1995 Confucianism and the Korean family. Journal of Comparative Family Studies 26:117-134.

Pyburn, K. ANNE

2008 Shaken, not stirred: The revolution in archaeology. Archaeological Papers of the American Anthropological Association 18:115-124.

RAPOPORT, Amos

1990 Systems of activities and systems of settings, in Domestic Architecture and the Use of Space: An Interdisciplinary Cross-Cultural Study: 9-20, ed. Susan Kent. Cambridge, UK: Cambridge University Press.

Robin, Cynthia, and Elizabeth Brumfiel, eds.

2008 Gender, Households, and Society: Unraveling the Threads of the Past and the Present. Archaeological Papers of the American Anthropological Association, 18(1). Malden, MA: American Anthropological Association.

Roth, BARBARA J.

2006 The role of gender in the adoption of agriculture in the southern Southwest. Journal of Anthropological Research 62:513-538.

2010a Introduction: Engendering households in the prehistoric Southwest, in Engendering Households in the Prehistoric Southwest: 1-11, ed. Barbara J. Roth. Tucson: University of Arizona Press. 
$2010 \mathrm{~b}$ Engendering Mimbres Mogollan pithouse occupations, in Engendering Households in the Prehistoric Southwest: 136-152, ed. Barbara J. Roth. Tucson: University of Arizona Press.

Ryu Ch'Un'GIL 류춘길 [Ryu ChUnGIL], No SANGGŎN 노상건 [No SANGGEON], AND SIN SŬNGWŎN 신승원 [SHIN SEUNGWON]

2012 Chinju P'yŏnggŏ 3-t'aekchi kaebal saŏp chigu (2-chigu) yujŏk ch'ult'o sŏkki mit sŏkche ŭi kogo chijilhakjŏk punsŏk kwa ${ }^{14} \mathrm{C}$ AMS yŏndae ch'ŭkchŏng 진주 평거 3 택지 개발사업지구(2지구) 유적 출토 석기 및 석재의 고고지질학적 분석과 ${ }^{14} \mathrm{C} \mathrm{AMS}$ 연 대측정 [Geoarchaeological Analyses of Stone Tools, Stones, and ${ }^{14} \mathrm{C}$ AMS Samples from the Pyeonggeo 3 Locality in Jinju], in Chinju P'yŏnggŏ-dong yujŏk: Chinju P'yŏnggŏ 3 t'aekchi kaebal saŏp chigu (2 chigu), IV [Locality 3-2 of the Pyeonggeo-dong Site, Jinju, Vol. IV]: 363-402. Ch'angwŏn: Kyŏngnam Munhwajae Yŏn'guwŏn.

Ryu Ch'Un'GIL 류춘길 [Ryu ChungIL], So Yunhwan 소윤환 [So Yunhwan], AND KIM CHISU 김지수 [KIM Jisu]

2012 Chinju P'yŏnggŏ 4-2 chigu yujŏk-ui yumul mit yugu punsŏk 진주 평거 4-2 지구 유적의 유물 및 유구 분석 [Analyses of Artifacts and Site at the Pyeonggeo 4-2 Locality in Jinju], in Chinju P'yŏnggŏ 4 chigu 2 kuyŏk yujŏk (ha) [Locality 4-2 of the Pyeonggeo Site, Jinju (Vol. II)]: 141-264. Kimhae: Tongsŏ Munmul Yŏn'guwŏn.

SCHRIEVER, BERNARD

2010 Evaluating the gendered division of labor in Mimbres households at a Late Pithouse-period short-term residential site, in Engendering Households in the Prehistoric Southwest: 153-184, ed. Barbara J. Roth. Tucson: University of Arizona Press.

SHOOCONGDEJ, RASMI

2002 Gender roles depicted in rock art: A case from Western Thailand, in In Pursuit of Gender: Worldwide Archaeological Approaches: 187-206, ed. Sarah M. Nelson and Myriam RosenAyalon. Lanham, MA: AltaMira.

SPAIN, DAPHNE

1992 Gendered Spaces. Chapel Hill: University of North Carolina Press.

Steadman, Sharon R.

2015 Archaeology of Domestic Architecture and the Human Use of Space. Walnut Creek, CA: Left Coast Press.

Tejeda, ANa S.

2008 Rethinking polity formation: A gendered perspective on formative period household development in the Pacific coast region of Guatemala. Archaeological Papers of the American Anthropological Association 18:87-101.

Tongǔi TAehakkyo Pangmulgwan 東義大學校博物館 [DONG-Eui University Museum]

2008 Chinju Taep'yŏngni Okpang 4-chigu sŏnsa yujǒk I 晋州 大坪里 玉房4地區 先史遺蹟 I [The Okbang 4 Locality of the Prehistoric Daepyeong-ri Site, Jinju, Vol. I]. Pusan: Tongŭi Taehakkyo Pangmulgwan.

TONGSŎ Munmul YŎN'GUWǑN 東西文物研究院 [DONG-SeO Institute OF Cultural Properties]

2012 Chinju P'yŏnggŏ 4-chigu II-kuyŏk yujŏk (sang) 晋州 平居 4地區 II 區域 遺蹟 (上) [Locality 4-2 of the Pyeonggeo Site, Jinju (vol. 1)], Kimhae: Tongsŏ Munmul Yŏn'guwŏn 東西文物研 究院.

Tringham, Ruth

1991 Households with faces: The challenge of gender in prehistoric architectural remains, in Engendering Archaeology: Women and Prehistory: 93-131, ed. Joan M. Gero and Margaret W. Conkey. Oxford: Blackwell.

WADLEY, LYN

1998 The invisible meat providers: Women in the Stone Age of South Africa, in Gender in African Prehistory: 69-81, ed. Susan Kent. Walnut Creek: AltaMira Press.

2000 The use of space in a gender study of two South African Stone Age sites, in Gender and Material Culture in Archaeological Perspective: 153-168, ed. Moira Donald and Linda Hurcombe. London: Macmillan Press.

Watson, Patty Jo, and Mary C. Kennedy

1998 The development of horticulture in the Eastern Woodlands of North America: Women's role, in Reader in Gender Archaeology: 173-190, ed. Kelley Hays-Gilpin and David S. Whitley. London: Routeledge. 
Wilk, Richard R., and William L. Rathje

1982 Household archaeology. American Behavioral Scientist 25:617-639.

Zihlman, Adrienne L.

1998 Woman the gatherer: The role of women in early Hominid evolution, in Reader in Gender Archaeology: 91-105, ed. Kelley Hays-Gilpin and David S. Whitley. London: Routeledge. 